支部・集談会記事

\section{日本臨床外科学会埼玉県支部抄録 （第31回埼玉県外科集談会）}

\author{
日時：平成25年11月16日（土） \\ 午後 1 時 \\ 会＼cjkstart場：埼玉県県民健康センター \\ 2 階大ホール \\ 支 部 長：丸 山 正 董
}

1 緊急手術を施行した血友病 $\mathrm{A}$ 患者の血気胸の 1 例 埼玉医科大学国際医療センター呼吸器外科

二反田博之、石田博徳、山㟝庸弘、坂口浩三、金子公一

28歳男性。呼吸困難にて前医を受診し左気胸の診断で当科へ紹介。 初診時は軽度の肺虚脱であったため安静を指示して帰宅。翌日の 胸部 X線写真で肺虚脱の進行と左下肺野透過性の低下を認めた。 既往歴で 1 歳時に血友病 A と診断されていたことが判明し、24 歳時の第VIII因子活性は $11 \%$ でった。再診時のAPTTは56.3秒 と延長していた。胸腔ドレナージで血性排液を認めたためドレナ ージから 5 時間で緊急手術を行った。手術室へ入る直前に第VIII 因子製剂2000単位を補充し、執刀直前の APTTは39.3秒と基準值 内であった。左鎖骨下動脈の外側に破綻した細い血管からの持続 的な出血を認め、これを凝固止血した後に肺尖部のブラを切除し た。出血量は $750 \mathrm{~mL}$ (術前ドレナージ400mL、術中吸引 $350 \mathrm{~mL}$ ) であった。術直後から抜糸が終了するまで第VIII因子の補充を 連日行った。

2 気管支鏡施行後に肺化膿症を併発し準緊急で手術した 肺癌の 2 例

埼玉県立循環器・呼吸器病センター 呼吸器外科

池谷朋彦, 鈴木 潤, 高橋伸政, 村井克己, 星 永進

症例 $1 ： 65$ 歳, 男性 喫煙：20本37年間 糖尿病で通院中, 体重 減少あり胸部 X線で右下肺野に $10 \mathrm{~cm}$ 大の腫瘤影あり紹介. 画像 上cT 3 N 2 M 1 a IV 期の肺癌疑い気管支鏡施行 $\rightarrow$ 翌日から高熱あ り軽快せず CTにて $11.5 \mathrm{~cm}$ まで増大. 肺化膿症制御不能と判じ 7 日目に右下葉切除術施行. 順調に経過し術14病日に退院.

症例 $2: 60$ 歳, 男性 契煙: 20 本40年間 高血圧で通院中咳痰あ り胸部X線で右下肺野に $6 \mathrm{~cm}$ 大の腫瘤影あり紹介. 画像上 cT 2 bN 0 M 0 II A 期の肺癌疑い気管支鏡施行 $\rightarrow 4$ 日目から発熱, 軽 快せず陰影増大し肺化膿症制御不能と判じ10日目に右下葉切除術 施行. 術後創感染, 哆開するも術 27 日目退院. 術後病理診断は 2 例とも多形癌. 緊急回避的に手術を施行し概ね良好な経過を得ら れたので報告する。
3 イレウスを契機に診断に到った空腸癌肺転移の 1 例 埼玉協同病院 外科

佐野貴之、岸本 裕、重吉 到、浅沼晃三、井上 豪、植田 守、 長潔、市川辰夫、井合 哲

症例は55歳女性。2011年健診にて貧血、便潜血陽性、胸部 X線 の異常影を指摘。上部消化管内視鏡検查にて胃潰瘍、十二指腸潰 瘍瘾痕、大腸内視鏡検查にて結腸㮩室を認めた。胸部 CTにて左 肺舌区に不整形結節認めたが、気管支鏡検查を拒否。その後、 2013年の胸部 CTで結節影増大傾向あり、気管支鏡検査施行。3 日後に嘔気煰吐で受診。腹部 CTにて胃・十二指腸の拡張あり、 空腸閉塞の診断。入院し、イレウス管にて減圧。悪性腫瘍考慮し、 2 週間後に手術（空腸部分切除）施行。病理は空腸癌の診断。そ の 1 ケ月後に胸部左肺上葉切除し、転移性肺癌の診断。単発の遠 隔転移を認めてから 2 年経過後に外科治療を実施した本症例につ いて、文献的考察を加えて報告する。

4 異なる経過をたどった前縦隔胚細胞性腫瘍の 2 手術例 埼玉医科大学総合医療センター 呼吸器外科

井上慶明、杉山亜斗、青木耕平、福田祐樹、儀賀理暁、泉陽太郎、 中山光男

症例 $1 ： 41$ 歳男性. 頭頸部の浮腫を主訴に近医受診し, CT で縦 隔腫瘍を指摘され当院紹介となった. CTガイド下生検で seminoma と診断，化学療法としてVIPを 3 コース施行した．著明な 腫瘍縮小を認めるも CRは困難と判断し, 残存腫瘍に対して根治 手術を施行した。

症例 $2: 33$ 歳男性. 胸痛を主訴に当科受診, CT で前腫瘍腫瘍を精 查の結果, non-seminomatous germ cell tumor と診断され，化 学療法としてBIP 2 コース, TIP 1 コース施行した. 来院時高值 であった $\mathrm{AFP} の$ 低下は認めたがCT上，腫瘍は増大していたた めPD と判断し，根治を目的として手術を行った

術前化学療法中に異なる経過をたどった前縦隔肧細胞性腫瘍の 2 手術例を経験したので報告する。

5 胸腔鏡下核出術を施行した食道神経鞘腫の 2 例 防衛医科大学校外科学講座

板崎勇二郎, 辻本広紀, 平木修一, 野村信介, 伊藤 希, 兼松恭 平, 長谷和生

症例 $1 ： 60$ 歳代, 女性, 心窩部痛にて上部消化管内視鏡を施行. 胸部中部食道に $5 \mathrm{~cm}$ 大の粘膜下腫瘍を指摘された。経過観察中, MRIにて腫瘍増大を認め手術となった。 症例 $2 ： 70$ 歳代, 女性, 検診での上部消化管内視鏡検查にて, 胸部上部食道に $2 \mathrm{~cm}$ 大の 粘膜下腫瘍を指摘された。 PET-CTにて腫瘍への集積を認め, 手術となった。いずれの症例も胸腔鏡下に腫瘍を摘出し, 術後合 併症無く軽快退院となった。 また病理組織所見では悪性所見はな く, 免疫学的にS-100蛋白陽性, c-kit, CD34, およびdesmin陰 性であり, 神経鞘腫と診断された

食道神経鞘腫は極めて稀であり，その報告は少ない。また食道粘 膜下腫瘍に対する胸胿鏡下核出術は低侵襲かつ診断的治療として 有用なオプションと考えられた.

\section{6 金属針による胃穿通に対する鏡視下手術の 1 例} 蓮田病院 外科

兼子 順、松井俊大、前島顕太郎、梶野紘平、杉本武哉、青柳治 彦、吉田 剛、長谷川久美、前島静顕

症例は81歳女性。心窩部違和感を主訴に来院した。腹部CTにて 
幽門前庭部前壁を貫通する high density 約 $3 \mathrm{~cm}$ の針状物を認 めた。患者は意識清明で異物を誤飲した記憶はなかった。上部消 化管内視鏡検査では、同部位に異常所見は認められなかった。腹 部MRIにて異物が磁性体だと判明したため、腹脉鏡下異物摘出 術をX線透視補助にて施行した。BMIが34.84 と高度肥満があり 内臓脂肪も多量存在していた。鏡視下で幽門前庭部も見づらく、 X線透視下にて金属針に近い大網を超音波メスにて切離を進めた ところ、金属震動音が認められ異物の所在が明らかになり摘出し た。今回の手術を鑑みると、内臓脂肪が多い症例は非金属性の異 物 (例えば魚骨等) 穿孔の場合、その局在診断が鏡視下手術では 困難であろう事が予想された。

\section{7 スプーン誤飲による十二指腸穿孔の 1 例}

埼玉社会保険病院 外科

檜垣瑛香、唐橋 強、铇沢一徳、溝田高聖、遠藤まり子、飯田修 史、吉水信就、関 みな子、櫻井孝志、中島顕一郎、細田洋一郎 症例は27歳女性。突然の上腹部痛を主訴に来院。腹部板状硬で腹 膜刺激症状を認めた。画像上スプーンの皿にあたる部分は十二指 腸下降脚内、柄の部分は肝下面の方向にあっり、free air、少量 の腹水を認めた。同日緊急手術施行。十二指腸球部前壁からスプ ーンの柄の部分が肝下面に向かって腹䐒内に露出していたが、周 囲臟器に損傷は認めなかった。スプーンを胃内へと用手的に還納 し、胃体部前壁を切開の後スプーンを摘出した。胃体部前壁切開 口および十二指腸穿孔部部を適宜縫合閉鎖した。術後経過は良好 で退院となった。また、入院中精神科依頼を行ったが明らかな精 神疾患は認めなかった。

スプーン誤飲による十二指腸穿孔の一例につき若干の文献的考察 を加え報告する。

8 腹腔鏡補助下幽門側胃切除 Roux-en-Y再建後の内へ ルニアの 1 例

草加市立病院外科

星野直明、西岡良薰、浅野大輔、杉本 斉、村山忠雄、近藤純由、 小野千尋

症例は78歳の男性、早期胃癌にて 4 年 7 か月前に腹腔鏡補助下幽 門側胃切除D $1+a$ 郭清、結腸前Roux-en-Y再建を施行した。 外来での経過観察中に時々上腹部痛が出現するも軽快していた。 3 日前より腹痛出現、症状の改善を認めず救急外来を受診し入院 となった。腹部CTでは輸入脚の拡張と空腸近位の軸捻転が疑わ れ内ヘルニアと診断し、症状軽快しないため翌日に手術を施行し た。開腹所見では腸管位置は正常であったが、輸入脚小腸が白色 調に肥厚し過去に嵌入を繰り返していたことが示唆された。また 十二指腸は著明に緊満していた。腹腔内の検索で挙上空腸と横行 結腸間膜の間隙 (Petersen's defect) が大網の癒着により狭小化 し半閉鎖の状態で門を形成していた。内ヘルニアの原因と判断し 間隙の縫合閉鎖を行った。術後上腹部痛の再燃は認めず。

9 食道癌術後の乳頭部癌に対して胃管温存膵頭十二指腸 切除術を施行した 1 例

越谷市立病院外科

嶋津 藍、牧野有里香、保母貴宏、野原茂男、杉山祐之、神山博 彦、武井雅彦、三浦弘善、行方浩二、津村秀憲、松本文夫 症例は72歳の女性、閉塞性黄疸の精査で乳頭部癌と診断された。 67歳時に下部食道癌に対して右開胸開腹食道亜全摘術三領域リン パ節郭清術を施行している。本症例に対して右胃動静脈拉よび右
胃大網動静脈の温存を含む胃管温存のPPPD-IIa を行った。 食道癌術後の胃管の血行は右胃動脈㧍よび右胃大網動脈が主なも のになる。文献上は本邦に 17 例の食道癌術後胃管温存膵頭十二指 腸切除術の報告がある。いずれの症例でも右大網動脈は温存され ている。静脈は切離された症例もある。動脈を温存できない場合 は、血管吻合や胃管切除および結腸再建などの術式が想定される が、まずは動脈温存の胃管温存膵頭十二指腸切除術を目指すべき であると考えられた。

10 胆囊捻転症に対して緊急腹腔鏡下胆囊摘出術を施行し

た 1 例

草加市立病院 外科

近藤純由、浅野大輔、杉本 斉、村山忠雄、小野千尋、星野直明、 西岡良薰

症例は83歳女性。上腹部痛を主訴に当院受診。腹部造影 CTにて 胆囊は著明に緊満し、壁が造影されなかった。胆囊頭側に胆囊管 が偏位しており、胆囊捻転症の診断にて入院当日に緊急手術を施 行した。腹腔鏡下に観察すると、胆囊は暗赤色を呈しており Gross I 型の遊走胆囊であった。胆囊頚部で時計方向に 180 度捻転 しており、捻転を解除し胆囊摘出術を施行した。病理診断では胆囊 全体は全層性壊死に陥っていた。術後 7 日目に軽快退院となった。

胆囊捻転症は重症急性胆囊炎に分類され、診断がつき次第手術 が望ましいとされている。高齢者での発症が多いため、早期診断 が重要である。本症例では術前診断しえたため、腹䏶鏡下手術を 選択し低侵襲な治療が可能であった。

11 齔歯による顎下膿瘍に合併した肝動脈瘤の 1 例 埼玉医科大学病院 消化器 - 一般外科

菅野優貴、高山哲嘉、森岡真吾、矢島沙織、山寺 彩、加藤环也、 小島和人、荻野直己、深野敬之、和田将栄、大原泰宏、多賀 誠、 淺野 博、篠塚 望

症例は71歳男性。激しい右季肋部痛を主訴に近医を受診し、腹部 造影 CTにて肝動脈瘤破裂が疑われたため加療目的に当院紹介と なった。腹部超音波検查では肝後区域に $2 \mathrm{~cm}$ 大の囊胞状病変が あり、ドプラにて動脈波形を認めていた。また入院前から䠘歯で 近医歯科に通院していたが、顎下膿瘍を合併しており、発熱や下 顎腫脹を認めていた。肝動脈瘤に対しては経カテーテル的血管内 コイル塞栓術を施行し止血した。また齲歯と顎下膿瘍に対しては 抜歯術、顎下部切開排膿術を施行した。

齲歯による顎下膿瘍に合併した肝動脈瘤の一例を経験したため若 干の文献的考察を含め報告する。

12 術前に膵管ステントを留置し核出術を施行しえた膵頭 部神経内分泌腫瘍の 1 例

丸山記念総合病院 消化器科 · 外科

大堀真毅、石井 博、大畑昌彦、高橋孝郎、高木 誠、米川 甫、 丸山正董、古川俊隆

症例は68歳・女性。健康診断にて $\gamma$ - GTP高值を指摘され当 院内科にて腹部超音波検査を施行。膵頭部に内部が不均一な $15 \times$ $10 \times 14 \mathrm{~mm}$ の腫瘍を認め平成 23 年 7 月 11 日当院初診。CTにて膵内 分泌腫瘍の疑いであった。腫瘍マーカーや各種ホルモン值は正常。 術式を考虑すると核出術の可能性もあり術中の膵管の局在を明ら かにし損傷を防ぐために ERCP施行時に膵管ステントを挿入し た。精查ののち 9 月 12 日手術施行。術中所見より核出術施行可能 と判断した。膵頭部を受動し背側よりアプローチし核出術をおこ 
なった。病理診断は endocrine tumor、Ki-67陽性細胞は目立た ず良性が示唆された。免疫染色では chromogranin A (+)、synaptophysin $(+)$ 、insulin $(-)$ 、glucagon $(-)$ 、somatostatin $(-)$ 、 pancreatic polypeptide $(+)$ であった。術後は膵管および胆管 に鋸歯状の狭窄をきたしたが保存的に軽快し順調に経過した。

今回我々は核出術を施行し得た膵頭部神経内分泌腫瘍を経験し たので報告する。

\section{3 腎細胞癌原発の転移性膵腫瘍の 1 切除例}

自治医科大学さいたま医療センター 消化器一般外科

桑原明菜、渡部文昭、野田弘志、力山敏樹

症例は73歳男性。1 年前に右腎細胞癌に対する根治的右腎摘出術 を施行（T 1 bN 0 M 0 Stage I ）。CT での経過観察中、膵尾部 に径 $2.2 \mathrm{~cm}$ の造影効果の強い腫瘤を認め、EUS-FNA で腎細胞癌 原発の膵転移が疑われた。手術は膵体尾部切除および脾摘出術を 行った。病理組織検查では clear cell carcinomaの所見で、腎細 胞癌の膵転移と診断した。腎細胞癌による膵転移の頻度は少ない ものの、転移性膵腫瘍の切除報告例は腎癌原発が最も多く、半数 以上を占める。腎癌原発の転移性膵腫瘍の切除例は予後良好な報 告が多く、積極的な外科的切除が考虑される。

14 膵粘液性囊胞腫瘍（MCN）との鑑別が困難であった 副腎囊胞（vascular cyst）の 1 例

獨協医科大学越谷病院外科 1 、同病理部 2 )

竹上正之 ${ }^{1)}$ 、久保田和 ${ }^{1)}$ 、菅又嘉剛1)、多賀谷信美 ${ }^{1)}$ 、大矢雅敏 ${ }^{1)}$ 、 上田善彦2)

膵 $\mathrm{MCN}$ との鑑別が困難であった副腎 vascular cystを経験し たので報告する。症例は65歳女性。腹痛に対して近医で行われた 腹部CTで左上腹部に囊胞性病変を発見され当科を紹介受診し た。当院受診時には腹痛はなく腫瘤も触知しなかった。CT、 MRIでは腫瘤は膵尾部に接して左腎上極の頭側に局在する、壁 の石灰化と壁在結節を伴った $10 \mathrm{~cm}$ 大の多房性囊胞性腫瘤であっ た。膵悪性 MCNを疑い開腹手術を行った。腫瘤は膵尾部下縁付 近の後腹膜より発生し、膵臓や腎臓とは連続性がなく腫瘤切除術 を施行した。組織学的には、腫瘤は線維性被膜で包まれた副腎皮 質と髄質の組織を有する多房性囊胞で、囊胞内腔面には血管内皮 による被覆とともにコレステリン沈着を伴うフィブリン血栓と担 鉄細胞の集簇が散見されvascular cystの診断であった。

15 Nuck管水腫内に子宮内膜症を合併した鼠径ヘルニア の 1 例

深谷赤十字病院外科

青木靖子、山田千寿、尾本秀之、石川文彦、新田 宙、藤田昌久、 釜田茂幸、相田俊文、高橋 誠、伊藤 博

33歳女性。未治療の子宮内膜症あり。左鼠径部の腫脹 - 疼痛を主 訴に受診。視触診㧍よびCTにて左鼠径ヘルニアと診断し、手術 を施行。

鼠径管を開放し、ヘルニア囊と思われた囊を切開すると、淡黄色 の漿液と黒褐色泥状の内容物を認めた。Nuck管水腫と判断し, 子宮円索とともに可及的に切除。水腫の中枢側には腹腔内と交通 する小さなへルニア囊を認めたため、高位結紮の上、Marcy 法で 閉鎖した。病理検査にて、内膜症を伴う Nuck管水腫と診断された。 成人における Nuck管水腫は比較的稀であるが、さらに水腫内に 子宮内膜症を合併した稀な症例を経験したので報告する。
16 右精巣腫瘍術後に発症した50歳代男性の右大腿ヘルニ アの 1 例

さいたま赤十字病院 外科 横田哲生、登内昭彦、仲田真一郎、横山元昭、吉留博之 症例は59歳男性。右鼠径部の腫瘤および疼痛を主訴に来院。3 年 前に右精巣腫瘍に対し高位精巣摘出術を施行した既往を持ち、来 院前日より右鼠径部の創痸痕近傍に鵎卵大の腫瘤および疼痛を認 め近医を受診し、右鼠径へルニア嵌頓疑いにて当科紹介となった。 腹部造影 CT 検查の結果右大腿へルニア嵌頓の診断にて緊急手術 を施行した。右鼠径部よりアプローチし、鼠径鞎帯の外側に突出 する sacを認めた。嵌頓腸管の虚血性変化を認めたため、ヘルニ ア門を縫合閉鎖、修復後に下腹部正中切開にて開腹し小腸部分切 除を施行した。

大腿へルニアは一般的に高齢者、特に女性に多い疾患であるが、 今症例は50歳代男性と比較的若く、稀少な症例を経験したため、 若干の文献的考察を加え報告する。

17 陰囊内まで達した再々発性腹壁㓔痕ヘルニアの 1 例 独立行政法人国立病院機構 埼玉病院 外科

江頭有美、原 仁司、金山和成、津和野伸一、柳 在勲、小西寿 一郎、早津成夫、吉竹公子、石塚裕人、原彰男

症例は67歳の男性。20年前に腸閉塞にて開腹手術をされた。6 年

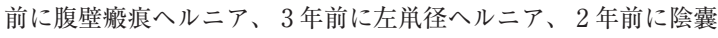
水腫と再発性腹壁瘏痕ヘルニアにて手術の既往あり。最終手術の 半年後に腹壁瘏痕へルニアが再々発し、陰囊まで増大したため当 院を受診した。下腹部正中にヘルニア門を認め、脱出した小腸は 恥骨前面を経て陰茎をよけ左右に分かれるように院囊内まで達し ていた。腹壁瘢痕へルニア修復術を施行し現在まで再発を認めて いない。陰囊内まで達した再々発性腹壁痺痕ヘルニアの 1 例を経 験したので報告する。

\section{8 咳嗽を契機に発症した腹直筋血腫の 1 例}

済生会栗橋病院外科

網木 学, 本田 宏, 正木紀行, 今泉理枝, 松本卓子, 内田靖子, 小池太郎

症例は76歳女性, 急性心不全でICU入院中，大きな咳嗽直後よ り右下腹部に膨隆が出現した。単純CTでは右下腹部腹壁直下か ら骨盤にかけてやや濃度の高い fluid collection を認めた。血腫が 疑われたものの出血点は明かではなく, 輸血による保存的加療を 行った. しかし, 約 5 時間後, プレショック状態となったため緊 急手術の方針となった．Cre5.3と腎機能悪かったが, 出血点同定 のために造影 $\mathrm{CT}$ を行った．右下腹部腹直筋後面に extravasasion を認め、下腹壁動脈出血と診断した。手術では断裂した右下腹壁 動脈を結紮止血した，血腫は腹膜前腔にのみ存在した．非外傷性 の腹直筋血腫は比較的稀な病態であるが，本症例のように急激な 経過をたどる症例があり，腹部出血の診断の際には必ず念頭に置 く必要があると考えられた.

19 急性虫垂炎を契機に発症した壊死性筋膜炎の 1 例 さいたま市民医療センター 外科

三島圭介, 塩谷 猛, 南部弘太郎, 渡邊善正, 小峯 修, 渋谷 肇, 山田太郎

46歳男性。1 週間前から右下腹部痛に対し鎮痛薬を内服してい たが改善しないため近医受診し, 穿孔性虫垂炎, 重症敗血症およ びDICの診断で紹介され緊急手術を施行した，穿孔した虫垂と 
後腹膜に膿瘍嘋を認め虫垂切除, 膿瘍ドレナージ術を施行した. 術後はDIC治療を行いながら，第 4 病日に㓌囊壊死に対して切 開排膿，第11病日に鼠径部から側腹部にかけての壊死性筋膜炎に 対して皮膚切開, デブリドメントを行った。 その後は創部洗浄, スキンケアを連日行い第67病日に退院した。精巣は温存できた。

壊死性筋膜炎は致命率が高く, 本邦での壊死性筋膜炎を伴う急 性虫垂炎の報告例は少ない. 壊死性筋膜炎においては積極的から 適切な時期に外科的処置を含めた集学的治療を行うことが重要だ と思われた。

20 手術歴のない小腸間膜裂孔ヘルニア陥頓による絞扼性 イレウスの 1 例

川口市立医療センター 消化器外科

伊藤栄作, 馬場優治, 伊藤恵理子, 原 圭吾, 野秋朗多, 黒部 仁, 栗原和直, 中林幸夫, 大塚正彦

【背景】成人の小腸間膜裂孔ヘルニア陥頓（以下，本症）による 絞扼性イレウスは比較的稀な疾患である.【症例】51歳女性. 手 術歴なし，突然の腹痛を主訴に当院外来を受診した。心窝部に限 局する腹膜刺激徵候を認め, 腹部造影 CTで小腸拡張と小腸腸間 膜の集簇を認めた．内ヘルニアによる絞抳性イレウスの疑い緊急 試験開腹術を行った. 回腸腸間膜に $3 \mathrm{~cm}$ の裂孔を認め, それに 陥頓し壊死した回腸を認めた。【考察】本症による絞扼性イレウ スは比較的稀な疾患であり, 成人の本邦報告例は本例を含め35例 である．本症の成因に関しては諸説あるが先天的に小腸腸間膜裂 孔が存在していることが多いと考えられている. 本症例も外傷歴 や腹部疾患の既往がなく, 先天的に小腸腸間膜裂孔が存在した可 能性が考えられた。本症の診断は難しいとされる. 成人の症例は 稀であるが手術歴のない小腸イレウスの鑑別として本症の可能性 を考慮し, 手術時期を逸することなく治療する必要があると思わ れた.

\section{1 盲腸周囲ヘルニアの 1 例}

坂戸中央病院 外科 1 、防衛医科大学校 外科学 21

滝川利通 ${ }^{1)}$ 、土屋長二 ${ }^{11}$ 、長谷和生 ${ }^{2}$

症例は89歳女性。亜腸閉塞にて当院内科入院となり、保存的に経 過観察するも改善せず、外科転科となった。腹部 CTにて右下腹 部での小腸閉塞が疑われたが、手術既往歴がなかったため、内へ ルニアを疑い、2013年 9 月手術となった。術中所見で盲腸周囲へ ルニアによる回腸嵌頓と診断し、嵌頓した小腸を癒着剥離しつつ 整復解除し盲腸後窩のヘルニア門を縫合閉鎖した後、嵌頓部の小 腸は剥離操作もあり脆弱となっていたため部分切除を施行した。 術後経過は良好で15PODに退院となった。盲腸周囲へルニアは まれな疾患であり、術前䛦断に苦慮することが多いとされている が、イレウスの原因腸管を盲腸周囲に認めた際には本疾患を鑑別 疾患の一つとして念頭に置く必要があると考えられた。若干の文 献的考察を加えて報告する。

22 術前に診断しえた S 状結腸間膜内ヘルニアの 1 例 益子病院外科

古川賢英、堤 純、高山澄夫、益子 博

症例は42歳男性、手術歴なし。腹痛を主訴に他院受診し、イレウ スの診断にて当院紹介となった。注腸後のイレウス管造影で $\mathrm{S}$ 状 結腸近傍の小腸に狭窄像を認め、同部位拡張腸管の内ヘルニア陥 頓状態が疑われた。このため、S 状結腸間膜内ヘルニアを最も疑 い、手術を施行した。腹腔鏡下では $\mathrm{S}$ 状結腸間膜内に嵌入した小
腸を認めたが、腹腔鏡下での整復が困難であったため、小開腹に てヘルニアを整復した。腸管血流は良好であり、ヘルニア門を縫 合閉鎖し、手術を終了した。術後経過は良好で術後第 9 病日に退 院した。S状結腸間膜内ヘルニアは稀な疾患であり、今回、術前 に診断しえた S 状結腸間膜窩内へルニアの1例を経験したので文 献的考察を加えて報告する。

23 小腸穿孔，出血性潰瘍をきたした腸結核の 1 例 さいたま市立病院外科

橋本知実, 茂田浩平, 山藤和夫, 窪地 淳 症例は43歳, 男性. 3 か月前から咳嗽と体重隇少を認め, 血痰を 主訴に救急外来を受診した. 結核と診断され抗結核薬を開始した. 第 5 病日で消化管穿孔を発症, 緊急手術で回盲部より口側 $100 \mathrm{~cm}$ に病変を認め, 小腸部分切除を施行した. 経過は良好であったが, 12病日から下血を認め, 17病日に再手術を行った。術中所見から 小腸潰瘍を出血源と判断し, 回盲部と回腸 $180 \mathrm{~cm}$ の切除を施行し た. 病理組織学的検査で, 非乾酪性壊死による穿孔, 潰瘍を認め た. 術後下血は認めなかったが, 経口摂取量が低下し低栄養とな った. 58病日に肝機能不全のため抗結核薬を中止，61病日に出血 傾向が顕著となり，62病日に死亡した。本症例は粟粒性結核に消 化管穿孔, 出血性小腸潰瘍を発症したもので比較的報告が少ない. 若干の文献的考察を加えて報告する.

\section{4 腹腔鏡下に手術を施行した空腸GIST の 1 例}

北里大学メディカルセンター外科

横田光央, 二渡信江, 本田 朋, 信太昭子, 小野里航, 近藤康史, 高橋禎人, 池永 誠, 西 八嗣

症例は 82 歳, 男性. 3 ケ月前に労作時胸痛を自覚した. 2 ケ月 前にも胸痛, 息切れ, 黒色便あり外来を受診した。血液検查にて $\mathrm{Hb} 5.3 \mathrm{~g} / \mathrm{dl}$ と貧血を認め入院した. CT検查にて空腸腫瘍が疑わ れた．経口小腸鏡で中心に陥凹を伴う約 $30 \mathrm{~mm}$ 大の粘膜下腫瘍が 認められた．空腸GIST の診断にて腹垫鏡下小腸部分切除術を施 行した。術後は経過良好であった.

切除標本では空腸に $27 \times 21 \mathrm{~mm}$ 大の粘膜下腫瘍を認めた。病理 組織検查では紡錘形の腫瘍細胞が漿膜下層に限局し, 核分裂像は $<5 / 50 \mathrm{HPF}$ であった，免疫染色ではc-kit，CD34，SMA陽性で あり, GIST, low risk群と診断した.

まれな空腸 GISTに対し腹腔鏡下にて切除した一例を経験した ので報告する.

\section{5 腹腔内出血で発症した小腸 GIST の 1 例}

新座志木中央総合病院 外科

谷島義章, 奈良橋喜芳, 吉野美幸, 岡田了祐, 長嶋 隆, 西田二 郎, 佐藤 滋, 吉田絋一

症例は33歳男性. 下腹部痛を主訴に当院受診, 腹部 CTで骨盤 内腫瘤と血液の混在する腹水譻留で入院. 翌日のCTで腹水と出 血が増加し緊急手術施行. $2500 \mathrm{ml}$ の血液と回腸末端から約 $70 \mathrm{~cm}$ 口側の回腸腸間膜対側の腫瘍が骨盤望に落ち込み, 周囲に発赤調 結節が散在, 腫瘍切除を施行. 病理検查でGIST high-risk と診断, 結節は播種であった. c-kit遺伝子検索でexon-11変異を確認, 術後よりイマチニブ内服, 術後 1 年経過現在再発兆候はない. GISTでの腹垫内出血は比較的まれであり若干の文献的考察を加 え報告する。 
1 例

秀和綜合病院外科 1 、同病理科 21

佐藤陽人 ${ }^{1)}$ 、桑原 博 $^{1}$ 、渡邊秀一 ${ }^{1)}$ 、劉 博 ${ }^{1}$ 、小川康介 ${ }^{1)}$ 、光 岡明人 ${ }^{1)}$ 、真田貴弘 ${ }^{1)}$ 、五関謹秀1)、小池盛雄 ${ }^{2)}$

症例は70代男性。2010年 8 月、直腸癌（RSRa Type $2, \mathrm{pSE}, \mathrm{pN}$ 1 :fStage-IIIa）に対し直腸前方切除術を施行。病理所見にて腫 瘍部に骨形成あり。術後UFT/LVによる補助化学療法を受けた が有害事象にて 2 コースで中止となった。以後経過観察されてい たが、2012年 9 月右下腿浮腫、11月にイレウス発症。CTにて右 下腹部に石灰化を伴う腫瘤を認め、腹腔内再発と診断し切除術を 施行した。病理所見上、直腸癌の再発であり、間質に骨形成を認 めた。骨形成性大腸癌自体比較的まれな疾患であるが、原発巣お よび再発巣の両者で骨形成を認めることは更にまれであるため、 若干の文献的考察を加え報告する。

\section{7} 大腸癌の穿孔を契機に発見された家族性大腸腺腫症 (FAP) の 1 例

埼玉医科大学総合医療センター 消化管一般外科

牟田 優、田島雄介、福地 稔、馬場裕之、熊谷洋一、石橋敬一 郎、持木彫人、石田秀行

家族性大腸腺腫症（FAP）は、約 $30 \%$ に家族歴がないため、若 年者においては、進行癌を合併するまで見落とされている可能性 がある。今回、大腸癌の癌部穿孔を契機に診断された FAPの 1 例を経験したので報告する。症例は36歳、女性。FAPの家族歴 なし。巨大子宮筋腫の治療中に腹痛を主訴に来院した。腹膜刺激 症状を有し、CT 検查でfree airを認め、下部消化管穿孔と診断し、 緊急手術を施行した。S状結腸に全周性の腫瘍性病変と同部位に 穿孔を認め、S 状結腸切除、人工肛門・粘液瘦造設術を施行した。 摘出標本の結腸粘膜には多発ポリープを認めた。術後の下部消化 管検査で、さらに直腸 $\mathrm{S}$ 状部に 1 型腫瘤と全大腸に多発ポリープ を認め、FAP と診断した。初回手術から56日目に結腸全摘・回 腸直腸吻合術、単純子宮全摘出術を施行した。

\section{8} 肝実質転移を認めない門脈腫瘍栓に対し系統的肝左葉 切除術を行った直腸癌の 1 例

埼玉協同病院 外科

市川辰夫、岸本 裕、重吉 到、佐野貴之、金子しお扮り、浅沼晃 三、井上豪、植田 守、長潔、井合 哲 静脈浸潤著明な直腸癌切術後の、肝実質転移を伴わない門脈腫瘍 检に対し、系統的な肝左葉切除術を行った症例を経験した。肝転 移に伴う門脈浸潤例の報告は多いが、実質転移を伴わない門脈腫 瘍栓例は稀であり、若干の文献的考察を行い報告する。

症例は68才の男性、200X年 8 月低位前方切除術 (D 2 (prxD 3 )) 施行。下腸間膜静脈内に腫瘍栓を認め左結腸静脈分岐上流で結紮 切離した。術後補助療法としてmFOLFOX 6 を12クール行った が、術後約 8 ケ月で門脈左枝に腫瘍栓を認め、術後約 10 ケ月で系 統的肝左葉切除術を施行した。

29 直腸癌の同時性両側副腎転移の 1 切除例

埼玉県立がんセンター 消化器外科

豊田哲鎬, 西村洋治, 八岡利昌, 横山康行, 島田 竜, 網倉克己, 川島吉之, 坂本裕彦, 田中洋一

症例は65歳の男性で，2012年12月直腸肛門管癌の診断にて近医よ り紹介となり，左側方リンパ節・左鼠径リンパ節に転移を認めた
ためCRTの方針となった

Capecitabine3600mg/day+40GyでCRTを施行したが, 終了後の 効果判定のCTにて両側副腎転移を認めた. Capecitabine failure として mFOLFOX+BV 開始. その後, PR となったため ISR+両 側側方リンパ節郭清 +両側副腎切除を施行した。

本邦における副腎転移切除の報告は検索しえた範囲内では38例と 少なく両側切除例はまれで本邦報告 4 例目である。 さらに同時性 の両側切除は本邦では報告がなく極めて稀である．今回直腸癌同 時性両側副腎転移の症例に対して切除しえた 1 例を経験したので 文献的考察を加えて報告する。

30 当院にて経験した異所性子宮内膜症の 2 例

秩父病院 外科

田邊智英，守麻理子，大野哲郎，山田正己，花輪峰夫

(1) 49 歳女性。 7 年前に子宮内膜症にて卵巣摘出術施行された。下 痢と血便を主訴に受診、注腸検査にて S 状部〜上部直腸に不整な 粘膜パターンと軽度の狭窄を認めた。大腸内視鏡検查では同部に $1 / 2$ 周性の結節状、発赤調の隆起した粘膜を認め、生検施行、 結果は group 1 であった。画像所見・病歴より腸管子宮内膜症を 疑ったため、高次医療機関に紹介。再度 $\mathrm{CF}$ 施行し、生検結果 から腸管子宮内膜症と診断した。その後症状は消失、CF で異常 所見は認めていない。

(2) 42 歳女性。受診 2 年前より肛門周囲痛自覚、肛門縁に胡桃大の 膿瘍を認め、他院にて切開排膿施行、創処置目的に当院紹介受診 した。 $1 \sim 3$ 時方向に硬結触知、痔瘦孔も認めた。痔瘦切除術施 行し、病理組織診にて異所性子宮内膜症と診断された。

異所性子宮粘膜症は他臓器に子宮内膜組織が増殖する病態で、 消化管に見られることは稀である。当院にて異所性子宮内膜症 2 例を経験したため、若干の文献的考察を加えて報告する。

31 腹部大動脈瘤術後、全直腸壊死した 1 例 埼玉医科大学国際医療センター 消化器外科

春田泰宏、森田洋平、原 聖佳、鈴木麻未、近藤宏佳、田代 浄、 石井利昌、山口茂樹、小山 勇

【症例】72歳男性【現病歴】突然の胸痛で受診し, 腹部大動脈瘤 破裂と診断された【既往歴】狭心症, 糖尿病, 舌癌【経過】CT上, 大動脈瘤破裂と診断し緊急手術施行. 左開胸で下行大動脈遮断下 に開腹．腎動脈下大動脈が破裂で Y-graft置換し，下腸間膜動脈

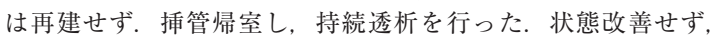
CT 撮影で両総腸骨動脈以下の血流は良好であったが下行結腸か ら直腸に造影不良な腸管を認め, 7 POD に再手術. 下行結腸か ら直腸にかけて血色不良で，切除することとした，肛門側は腹膜 翻転部以下も血色不良で, Mile's手術を行った。横行結腸は血色 良好で人工肚門造設した．改善なく $18 \mathrm{POD}$ に永眠.【考察】腹部 大動脈瘤術後の全直腸の虚血は報告がなく稀と思われ報告する。 